\title{
SOME NEW MATERIAL ON ROBERT DICK, BAKER OF THURSO, GEOLOGIST AND BOTANIST
}

\begin{abstract}
$\mathbf{I}_{\mathrm{g}}^{\mathrm{N}}$ December 1866, Robert Dick, baker of Thurso, geologist and botanist, died after a few weeks of illness. Forgotten and neglected by most of his townsmen, his name was a household word to many of the learned men of his day. He was the great shadow behind Hugh Miller (author of the Old Red Sandstone), and many of Dick's fossils were figured in later editions of this book. Dick discovered two new fishes: Coccosteus minor, now known as Millerosteus minor (Hugh Miller), and Homosteus milleri, erroneously ascribed to Asterolepis by Louis Agassiz, the Swiss naturalist. It has since transpired that the fish known to Dick as Coccosteus decipiens is, in fact, a new genus: Dickosteus thrieplandi (Miles and Westoll, 1963).

Sir Roderick Murchison, controller of the Geological Survey of Great Britain, visited Dick on several occasions and was instructed by him on the geology of Caithness, Dick making a geological map out of flour in his bakehouse. When Lucien Buonaparte called on Dick at his bakehouse he sent word that the prince must call at a more convenient time as the bread would wait for no man.

His entire collection of fossils had to be sold to pay for the loss at sea of a cargo of flour-he received $£ 60$ for them. He made a very thorough collection of botanical specimens from Caithness and confounded many experts with his knowledge. Among other things he discovered Hierochloe borealis (now called Hierochloe fragrans), the Northern Holygrass, growing near Thurso. He also made a collection of insects of Caithness which has, unfortunately, perished owing to neglect. A further collection was of native shells; the collection was lost.
\end{abstract}

Recent work by volunteer labour on the Dick collection has brought to light hundreds of botanical specimens, the existence of which was hitherto unknown, together with a collection of shells, some identified in Dick's handwriting, which must be the Dick collection of shells.

If further proof of the authenticity of the new material were required there are three envelopes containing botanical specimens addressed to Mr. Robert Dick, Baker, Thurso; two are postmarked 1859 and 1860 , but the third is far older and bears an imperforate penny red. This must date from between 1841 and 1850. The letter was originally sealed with red wax and appears to have come from Prof. Owen.

There is also a parcel of grasses from a Mr. Notcutt, druggist, addressed to Mr. Dick, Thurso. Notcutt is mentioned in the biography by Smiles.

There are several pieces of paper which refer to correspondence in The Witness, and are concerned with a difference of opinion between a Mr. Rhind and Hugh Miller. They appear to be the draft of a reply to Rhind's criticisms and clearly refer to a press cutting signed "A Country Geologist". The subject is the Deluge and geological evidence that the sea level has not always been in its present position with regard to the dry land.

There are also notes on a stratigraphical succession concerning gneiss, quartzite, red conglomerate and limestone. This would seem to refer either to the area round Scaraben or to the vicinity of the Moine thrust plane.
J. SAXON
J. I. Bramman
N. CAMPBELL

\section{OBSERVATIONS OF SUDDEN IONOSPHERIC FREQUENCY DEVIATIONS AT WIDELY SEPARATED PLACES}

\author{
By D. M. BAKER, DR. K. DAVIES and L. GRIMES*
}

Institute for Telecommunication Sciences and Aeronomy†, Environmental Science Services Administration, Boulder, Colorado

$\mathrm{R}^{\mathrm{A}}$ APID fluctuations are sometimes observed in the received carrier frequencies of ionospherically propagated high-frequency radio waves ${ }^{1-4}$. Some of these frequency fluctuations, which can be readily identified from the records, have been called sudden frequency deviations, and have been attributed primarily to electron content changes in the $E$ and $F$ regions of the ionosphere caused by ionizing radiation from solar flares ${ }^{1,2}$. Munro ${ }^{5}$, however, has suggested that the observed effects may be the result of travelling ionospheric disturbances. The purpose

* Guest worker on leave from the Department of Physics, University of Ghana, Legon.

$\uparrow$ Formerly designated Central Radio Propagation Laboratory of the National Bureau of Standards. Table 1. Cikcuits over which Doppler Measurements have been Made and which have BeEn tSed in the analysis of the Suddex Frequexcy

\begin{tabular}{|c|c|c|c|c|c|c|c|}
\hline \multicolumn{3}{|c|}{ Transmitter } & \multicolumn{3}{|c|}{ Receiver } & \multirow{2}{*}{$\begin{array}{c}\text { Path length } \\
(\mathrm{km})\end{array}$} & \multirow{2}{*}{$\begin{array}{c}\text { Frequency } \\
(\mathrm{Mc} / \mathrm{s})\end{array}$} \\
\hline Location & Latitude & Longitude & Location & Latitude & Longitude & & \\
\hline $\begin{array}{l}\text { Monrovia, Liberia } \\
\text { Liberia }\end{array}$ & $\begin{array}{l}6 \cdot 22^{\circ} \mathrm{N} \\
6 \cdot 22^{\circ} \mathrm{N}\end{array}$ & $\begin{array}{l}10 \cdot 46^{\circ} \mathrm{W} \\
10^{\circ} \cdot 46^{\circ} \mathrm{W}\end{array}$ & $\begin{array}{l}\text { Acera, Ghana } \\
\text { Natal, Brazil }\end{array}$ & $\begin{array}{l}5 \cdot 33^{\circ} \mathrm{N} \\
5 \cdot 46^{\circ} \mathrm{S}\end{array}$ & $\begin{array}{l}0 \cdot 15^{\circ} \mathrm{W} \\
35 \cdot 15^{\circ} \mathrm{W}\end{array}$ & $\begin{array}{l}1,180 \\
2,990\end{array}$ & $\begin{array}{l}10 \cdot 1018 \\
20 \cdot 2038 \\
10.1018\end{array}$ \\
\hline Washington, D.C. & $39 \cdot 02^{\circ} \mathrm{N}$ & $76.55^{\circ} \mathrm{W}$ & Boulder, U.S.A. & $40.02^{\circ} \mathrm{N}$ & $105 \cdot 16^{\circ} \mathrm{W}$ & 2,430 & \\
\hline Sunset (Boulder) & $40 \cdot 03^{\circ} \mathrm{N}$ & $105 \cdot 50^{\circ} \mathrm{W}$ & Boulder, U.S.A. & $40 \cdot 02^{\circ} \mathrm{N}$ & $105 \cdot 16^{\circ} \mathrm{W}$ & 25 & $\begin{array}{l}5 \cdot 054 \\
4.000\end{array}$ \\
\hline Maui, Hawaii & $20 \cdot 56^{\circ} \mathrm{N}$ & $159 \cdot 29^{\circ} \mathrm{W}$ & Honolulu, Hawaii & $21 \cdot 18^{\circ} \mathrm{N}$ & $157 \cdot 40^{\circ} \mathrm{W}$ & $\sim 100$ & $5 \cdot 0$ \\
\hline
\end{tabular}

of this report is to present a few examples as evidence to show that these frequency deviations are indeed produced directly by fluctuations in solar ionizing radiation at the time of a flare rather than by some form of local iono. spheric disturbance.

Munros pointed out: "that since the ionospheric effects of a solar flare are due to ultra-violet radiation they should all be observed simultaneously over the sunlit surface of the earth". This is a crucial point, and an opportunity has arisen to verify that the frequency-deviation effects are simultaneous over a large area of the Earth through a network of radio circuits established by the Institute for Telecommunication Sciences and Aeronomy. A list of the relevant eireuits is given in Table 1 , from which it 